\title{
Recenzja
}

\section{Marcin Olszówka, Konstytucja PRL a system źródet prawa wyznaniowego do roku 1989, ISBN 978-83-64054-22-8, Oficyna Wydawnicza Uczelni Lazarskiego, Warszawa 2016, ss. 122}

Autor recenzowanej monografii - Marcin Olszówka - to doświadczony badacz stosunków konfesyjnych, twórca cenionych w środowisku naukowym publikacji z tego zakresu. Jego najnowsza książka to pogłębiona analiza kształtowania systemu źródeł prawa wyznaniowego pod wpływem Konstytucji PRL. Badaną problematykę Autor prezentuje na tle systemu źródeł prawa PRL, co pozwala Mu stwierdzić, że jego specyfika negatywnie oddziaływała na źródła prawa wyznaniowego, a poprzez nie - na status ustrojowy kościołów i związków wyznaniowych oraz realizację wolności sumienia i wyznania. Wyraźnie zaznacza, że stosunek władz komunistycznych do kościołów i związków wyznaniowych, religii i religijności był nacechowany uprzedzeniami, a okresowo wręcz obsesjami antyreligijnymi, co wynikało z postrzegania religii jako kluczowej przeszkody w budowie państwa komunistycznego i formowania człowieka komunistycznego. Prawo wyznaniowe PRL było jednym z instrumentów sprawowania polityki wyznaniowej, zdeterminowanej założeniami ideologicznymi, co z kolei rzutowało na sposób jego kształtowania.

Autor prawidłowo określa cele publikacji. Czyni to w sposób wyraźny. Zasadnie zaznacza, że analiza wpływu konstytucji na system źródeł prawa wyznaniowego nie może abstrahować od konstytucyjnej koncepcji relacji państwa ze związkami religijnymi oraz gwarancji wolności sumienia i wyznania. 
Ich realizacja następuje w drodze konkretnych źródeł prawa wyznaniowego. Marcin Olszówka celnie dostrzega, że specyfika systemu źródeł prawa w Polsce Ludowej, jego tzw. rozchwianie, negatywnie oddziaływała na traktowanie przez organy państwa związków wyznaniowych i ich członków. Innymi słowy, sposób tworzenia prawa miał wpływ na jego stosowanie.

Autor analizuje wpływ Konstytucji PRL z 22 lipca 1952 r. na system źródeł prawa wyznaniowego. Recenzowana publikacja jest przy tym nie tyle opisem systemu źródeł prawa wyznaniowego, ile ukazuje sposób oddziaływania Konstytucji PRL na ten system. Jak zasadnie podnosi Marcin Olszówka, wpływ Konstytucji PRL na system źródeł prawa wyznaniowego jest wypadkową trzech czynników. Pierwszym z nich jest konstytucyjna koncepcja systemu źródeł prawa. Źródła prawa wyznaniowego - będąc częścią systemu - ex definitione podlegają panującym w systemie regułom. Drugim jest odwołanie się przez ustrojodawcę bezpośrednio w przepisach wyznaniowych do konkretnych przedmiotowych źródeł prawa, za pomocą których należy regulować wybrane kwestie z zakresu prawa wyznaniowego. Trzeci aspekt to konstytucyjne ujęcie stosunków państwo - kościół, czyli zdefiniowanie naczelnych zasad prawa wyznaniowego. Pod kątem tak zidentyfikowanych mechanizmów wpływu konstytucji na system źródeł prawa wyznaniowego Autor prowadzi rozważania. Czyni to w sposób skrupulatny i ze znawstwem.

Badając wpływ Konstytucji Polskiej Rzeczypospolitej Ludowej z 22 lipca 1952 r. na system źródeł prawa wyznaniowego Autor udowadnia, że opisywany system ze strukturalnego punktu widzenia niewiele odbiegał od kształtu ówczesnego systemu źródeł prawa. To właśnie ten aspekt wpływu (spośród trzech wyodrębnionych przez Autora książki) był dominującym mechanizmem oddziaływania Konstytucji PRL. Ponadto istotną rolę odegrało odwołanie się w Konstytucji z 1952 r. do konkretnego przedmiotowego źródła prawa w znaczeniu formalnym, czyli ustawy.

W praktyce nierzadko ogromną rolę odgrywały akty tzw. prawa powielaczowego. Modyfikowały one treść przepisów aktów ustawodawczych i wykonawczych. Uzupełnieniem negatywnych praktyk prawotwórczych był również fakt, iż część aktów tzw. prawa powielaczowego jedynie powtarzała treść normatywną zawartą w obowiązujących aktach normatywnych. W ten sposób identycznie zatytułowane akty, pochodzące od tych samych podmiotów, mogły mieć raz charakter prawotwórczy, a raz nieprawotwórczy lub i taki, i 
taki. Skutkowało to zwiększeniem niepewności co do obowiązującego w danym momencie stanu prawnego, co dodatkowo negatywnie wpływało na status związków wyznaniowych i ich członków.

Przechodząc do szczegółowych ustaleń, recenzowana monografia złożona jest z trzech rozdziałów. Chcąc uplasować system źródeł prawa wyznaniowego na tle Konstytucji PRL, zasadnie w pierwszym z nich Autor poddaje analizie samą koncepcję systemu źródeł prawa w PRL. W związku z nią dowodzi, że w Konstytucji z 22 lipca 1952 r. nie tylko nie określono wyczerpująco wszystkich elementów systemu źródeł prawa, ale nawet nie wymieniono wszystkich podstawowych. Jego niedookreślenie pozostawiało otwartą drogę do mnożenia różnych postaci aktów normatywnych. W rezultacie wydawano pozaustawowe akty prawotwórcze, podejmowane na podstawie upoważnień zawartych w aktach organów administracji czy też subdelegowanych kompetencji. Tłumaczono bowiem, że skoro nie jest ona konstytucyjnie zakazana, a zarazem nie sprzeciwia się jej Sejm, to znaczy, że może być ona praktykowana. Ten stan rzeczy zaczął ulegać zmianie dopiero w połowie lat 80. XX w., wraz z rozpoczęciem działalności orzeczniczej przez Trybunał Konstytucyjny. Choć system źródeł prawa pozostał otwarty, tym niemiej dzięki orzecznictwu Trybunału stawał się on bardziej uporządkowany.

W drugim rozdziale Marcin Olszówka analizuje konstytucyjne ujęcie stosunków państwo-kościół w Polsce Ludowej. Dowodzi, że wskazuje ono, że wolą ustrojodawcy było nadanie państwu charakteru laickiego oraz sekularyzacja stosunków publicznych. Nadanie państwu charakteru socjalistycznego oraz faktyczne sprawowanie władzy przez partię komunistyczną sprawiły, że relacje państwo-kościół przypominały system zwierzchnictwa państwa nad kościołem, w którym religią oficjalną był ateizm, a konstytucyjnie zdefiniowane wolność sumienia i wyznania niewiele miała wspólnego z tym, czym wolność sumienia i wyznania są w państwie prawnym. Konstytucja z 22 lipca 1952 r. dwojako oddziaływała na system źródeł prawa wyznaniowego. Po pierwsze, wpływała poprzez konstytucyjną koncepcję systemu źródeł prawa, a po drugie - poprzez bezpośrednie odwołanie się przez ustrojodawcę w przepisach wyznaniowych do konkretnego przedmiotowego źródła prawa. Natomiast sama treść materialnoprawnych przepisów wyznaniowych zawartych w Konstytucji w nieporównywanie mniejszym stopniu ingerowała w system źródeł prawa wyznaniowego. 
Ostatni rozdział książki jest poświęcony źródłom prawa wyznaniowego w PRL. Słusznie Autor dowodzi, że system źródeł prawa wyznaniowego był częścią otwartego systemu źródeł prawa w Polskiej Rzeczypospolitej Ludowej i jako podsystem charakteryzował się tymi samymi cechami co całość, tak co do struktury, jak i składu. Oprócz tego Autor recenzowanej książki zidentyfikował pewne elementy specyficzne i właściwe tylko rozważanemu podsystemowi, związane przede wszystkim z obecną w polskim prawie wyznaniowym tradycją bilateralności (dwustronności) i wymogiem konsensualności. Organy władzy państwowej zawierały z podmiotami konfesyjnymi porozumienia i umowy. Choć typowo nie miały one cech źródeł prawa, lecz były aktami stosowania prawa jako źródła zobowiązań także dla organów władz państwowych, to pod koniec lat 80. umowa ze związkiem religijnym, jako odrębne źródło prawa, została potwierdzona przez Sejm. Z konsensualnością prawa wyznaniowego okresu Polski Ludowej Autor wiąże zasadę bilateralności. Jej przejawem jest tzw. ustawodawstwo partykularne przyjęte na podstawie przepisów Konstytucji z 1921 r. i utrzymane w mocy przez przepisy Konstytucji z 1952 r. Choć proklamujący zasadę oddzielenia kościoła od państwa prawodawca nie zakładał dalszego funkcjonowania zasady dwustronności to jednak okazała się ona trwałym sposobem regulowania stosunków zachodzących między państwem a konkretnym związkiem religijnym.

Jak zasadnie podnosi Autor, w okresie Polski Ludowej system źródeł prawa wyznaniowego był częścią otwartego państwowego systemu źródeł prawa. Jako jego podsystem charakteryzował się tymi samymi cechami, co całość, tak co do struktury, jak i składu.

$\mathrm{Na}$ tle całościowej analizy recenzowanej monografii trzeba stwierdzić, że wyrażane przez Autora tezy są właściwe, prawidłowo udokumentowane i uzasadnione. Znaczenie porządkujące mają ustalenia terminologiczne. Są one rozbudowane i wiele wnoszą do analizowanej tematyki. Na podkreślenie zasługuje również wykorzystana przez Autora bogata baza źródłowa.

Rekapitulując, pracę cechuje rozległa prezentacja ustaleń doktryny i orzecznictwa z okresu PRL. Nierzadko jest to nowe spojrzenie na zagadnienia, które wydawałoby się, że już dawno powinny zostać wyjaśnione, co czyni recenzowaną publikację nowatorską, a przez to ważną dla badaczy prawa wyznaniowego, jak również prawa konstytucyjnego. Pomimo wie- 
lu publikacji dotyczących prawa wyznaniowego PRL, tak powstałych przed 1989 r., jak i w okresie późniejszym, brakowało monografii poświęconej systemowi źródeł prawa wyznaniowego PRL. Dobrze się więc stało, że powstała i że jej Autorem jest Marcin Olszówka - doświadczony i rzetelny badacz stosunków konfesyjnych.

Jacek Zaleśny Uniwersytet Warszawski 